\title{
Applications of Vygotskyan Concept of Mediation in SLA.
}

Carmen Helena Guerrero Nieto

\begin{abstract}
The application of Vygotskian ideas is not new to education, research studies abound reporting various ways in which they can be applied. But in the particular field of Second Language Acquisition a Vygotskian approach is rather new, with the first studies dating from about mid 1990s. In this article I discuss one Vygotskian concept, mediation, and report on some research studies that have been framed in this concept. I found that the studies surveyed could be grouped according to the type of mediation, therefore three categories emerged: Mediation by dialoguing with one self, Mediation by dialoguing with the other, and mediation through technology.
\end{abstract}

Key words: Mediation, Second Language Acquisition, Socio cultural theory, symbolic tools.

\section{Resumen}

La aplicación de las ideas de Vygotsky no es nueva en el campo de la educación, de hecho, abundan investigaciones que reportan formas diferentes en que éstas se pueden usar. En el campo específico de Adquisición de la Segunda Lengua, el enfoque Vygotskiano es mas bien nuevo; los primeros estudios datan de mediados de los años 90. En el presente artículo, se discute uno de los conceptos Vygotskianos, el de la mediación. Además se reporta sobre once estudios que han explorado este concepto. Los estudios reportados se agruparon de acuerdo con la forma de mediación que primó en cada uno de ellos, de manera que surgieron tres categorías: Mediación a través del diálogo con uno mismo, Mediación a través del diálogo con el otro, y Mediación a través de la tecnología.

Palabras claves: Mediación, Adquisición de una segunda lengua, teoría socio-cultural, herramientas simbólicas.

\footnotetext{
* Received: 02-05-07/Accepted 09-08-07
} 


\section{Introduction}

Vygotskyan ideas about education have brought a new and fresh air to the field of SLA. For decades, SLA teachers were inspired by theory and research that equated the mind to a computer, implying with this metaphor a kind of "banking" mode of education in which the teacher would put input in the mind of the individual and he/she would produce an output of the same characteristics of the input received. In this event of input-output the learner should rely on his/her own strategies to learn because it was believed that any kind of interaction with others would contaminate him/her with the others' mistakes.

This panorama has started to change, in some contexts more than in others, thanks to the spread of the ideas of the Russian psychologist Lev Vygotsky in the Western world. The new acquaintance researchers and teachers have with what is known as sociocultural theory, has led to a bulk of research that explores the applications of its principles in the field of SLA in the classroom. In my opinion, this has meant an important gain for education, because the school, the classroom, the teacher, and the learner are now seen and valued from a different perspective, one that is much more holistic and situated and that recognizes the complexity of learning a second language, and therefore, the necessity to interact with others to fulfill this purpose.

According to John-Steiner and Mahn (1996) sociocultural approaches highlight the relationship between social and individual processes in the coconstruction of knowledge. They state that Vygotsky and his collaborators are the founders of the sociocultural cultural theory and that "They are based on the concept that human activities take place in cultural contexts, are mediated by language and other symbol systems, and can be best understood when investigated in their historical development" (p. 191) This approach has also been called cultural historical but for the sake of this paper and taking into account that all the articles surveyed here use the term sociocultural, I will use it along the article.

The concepts and ideas drawn from the Sociocultural Theory have been explored by researchers as well as teachers in different contexts of SLA, either with children, adolescents, or adults. Extensive amounts of research studies have documented the applications of ZDP, Peer interaction, Play in SLA, etc. All these tenets are interconnected and belong to the same umbrella term of mediation. In that which follows I will present a theoretical discussion of this term. 
According to Lantolf (2001) one of the main concepts of the Sociocultural Theory is that the mind is mediated. This means that the individual does not establish a direct relationship with the world, but that this relationship is mediated through the use of tools. Vygotsky (1978) borrowed the concept of tools from Hegel and Marx and he states that "Marx cites that definition when speaking of working tools, to show that man uses the mechanical, physical, and chemical properties of objects so as to make them act as forces that affect other objects in order to fulfill his personal goals" (p. 54) Individuals, in collaboration with others, used tools to control the world according to their needs and goals and in this sense, tools become mediators between the subject and the object. Kozulin (1998) states that Vygostky identified three kinds of mediators: material tools, psychological tools and other human beings.

Regarding the material tools, Kozulin claims that "they presuppose collective use, interpersonal communication, and symbolic representation" (p. 62). Of the material kind of tools we can mention anything the human being has invented to master nature (Vygotsky, 1978) from wood sticks to lap tops; the invention and use of material tools have transformed our way of thinking which has different consequences for each individual. Cole (2003) presents the example of the invention of money as a material tool to mediate in human transactions of goods, and shows how this invention has shaped the thinking of modern societies.

The role of psychological tools is to mediate the psychological processes of humans. These tools have been transformed along the history of human beings; for example, the primitive humans used such psychological tools as casting lots, tying knots, and counting fingers (Kozulin, 1998) to mediate between their mind and the abstract world, and modern societies have transformed and updated these tools. The result of the upgrade of some of these tools is known as "symbolic tools" and among them there are numbers, arithmetic systems, music, art, and language (Lantolf, 2000). Symbolic tools belong to what Vygostsky (1978) called "higher intellectual processes", and are strictly human.

The third type of mediation is through another individual. Vygoskty (1978) supports this idea in the following example: a child wants to grasp an object which is beyond his reach. In trying to do so, he points at it in an attempt to establish a direct relationship with the object. His/her mother comes to aid him/her interpreting the pointing as indexing the desire to reach the object. In this moment, pointing becomes a sign for others. When the child realizes 
the change in the function of pointing, its orientation changes, too. From this moment on the child will use the pointing to establish relationship with others and not with the object. The mother in this case, has become the mediator who helps the child reach his/her goal, through another mediation tool: pointing. Mediation then is the way in which humans establish a relationship between their mental representations and the world. As we will see below, mediation can take different forms.

By and large, these forms of mediation principles about mediation have led researchers in SLA to explore their applications in real classroom settings. In what follows I present a compilation of eleven studies carried out in different parts of the world whose main core is mediation in any of the three forms described above.

\section{Discussion}

Throughout the reading of this set of articles I found some common aspects among studies and I decided to group them in three categories. I assigned a name to each category depending on the aspect that joined the group of studies together, considering if the mediation was using a symbolic tool (language) or other human beings, or a material tool. As a result the three categories are: Mediation by dialoguing with one self, Mediation by dialoguing with the other, and mediation through technology.

\section{Mediation by Dialoguing with one self: language as a mediator in SLA}

As stated above, Vygotsky (1978) considered language as a symbolic tool that allows human beings to mediate between their minds and the outside world. This is especially true if the outside world means learning another language. In a comparison Vygotsky (1962) makes of teaching children scientific concepts and a foreign language, he states that:

"direct teaching of concepts is impossible and fruitless. A teacher who tries to do this usually accomplishes nothing but empty verbalism, a parrotlike repetition of words by the child, simulating a knowledge of the corresponding concepts but actually covering up a vacuum" (p. 83)

From his words it can be concluded that the mere role of a teacher is not enough to generate learning. Many SLA teachers are aware of this fact, and in their search to promote learning among their students, they implement 
strategies that help learners mediate between what they know (their actual zone of development) and what they would like to achieve (the ZDP). In accomplishing this task, teachers have generated many strategies like logs, journals, conferences, self assessment, tasks, portfolios, etc.

Portfolios have been used widely by teachers as a way for learners to keep track of their work and achievements. Donato, and McCormick (1994) implemented the use of portfolios with the purpose to engage in a self dialogue a group of college students who were learning French as a second language. The researchers wanted to demonstrate that "the development of language learning strategies is mainly a by-product of mediation and socialization into a community of language learning practice" (p. 453), because they consider that the classroom is central to the individuals' development of their own learning strategies. This statement is supported by Vygotsky's idea that any aspect of the cultural development of the child appears first on the social level (interpsychological) and then on the individual level (intrapsychological). (Vygotksy, 1978, 57).

The researchers found that using portfolios as a tool in which students could assess their own learning, led them to examine critically their own learning and eventually led them to discover and implement learning strategies in order to improve their command of the L2.

Another study that explores the advantages of using language to dialogue with the self was conducted by Appel and Lantolf (1994) who examined the role of speaking in what Vygotsky calls inner speech.

Vygotsky conducted experiments to demonstrate the importance of egocentric speech and established that children speak while performing a task as a way to understand it and accomplish the goals set in it. Piaget (2001)considered that egocentric speech was not relevant and that it would eventually disappear when children approached school age; Vygotsky (1962), instead, considers that egocentric speech does not disappear but transforms itself in what he calls inner speech. Other researchers have tried to define these terms and have created others that in some cases are used interchangeably: Private speech, inner speech, self-directed speech, verbal thought, thinking aloud, and communicative speech. According to Centeno-Cortes and Jimenez Jimenez (2004) Flavell in 1964 coined the term private speech, in order to dissociate Vygotsky's egocentric speech from Piaget's notion and Wresch (1985) 
spread its use in the field of cognitive psychology and linguistics. Due to the variety of terms and interpretation, in this paper, in this section I will use the term preferred by the researchers of each study reported here (private speech).

Based on the premise that "human speech has a dual mediational macrofunctions-a primary function, to mediate our social activity, and a secondary function, to mediate our mental activity" (Appel and Lantolf, 1994: 439) the researchers designed a study intended to document and analyze the role of private speech (aloud) in two recall tasks. They presented a narrative text and an expository text to a group of fourteen native speakers of English and fourteen speakers of ESL. The students had to prepare a protocol to retell the story to the researchers. During this process, each student would be alone in an office, and his/her speech would be recorded while preparing for the oral report.

The analysis of data shows that in fact, both native and non native speakers of English rely on dialogue with the self in order to accomplish the task mentioned above. The way in which the NNS engaged in the dialogue with the self, according to the data reported by the researchers, was through asking themselves questions, and talking in third person. This finding once more demonstrates, as I noted above, Vygoskty's theory that speech plays a crucial role not only in accompanying the performance of a task, but in understanding it and achieving its goals.

In an attempt to document the characteristics of private speech, Ohta (2001) studied a group of seven first and second year learners of Japanese. Ohta considers that private speech can provide a window to understand the process of language acquisition, because it can reveal L2 internalization processes.

She found three main characteristics of private speech: 1) Vicarious response, which she defines as an answer covertly produced by a learner when the question is addressed to another learner. 2) repetition that is when the learner repeats after the teacher, another student or him/herself; it is covert too and in low voice or whisper and 3) manipulation, and it happens when the learner repeats language forms in order to play with their grammatical, morphological, or semantic structure.

Ohta concludes that private speech fulfills an important role as a mediating tool for L2 learning, because it allows the learner to have a dialogue with the self, hypothesize about L2 language, evaluate his/her knowledge, and practice freely before speaking out. 
By and large, the articles reported above examined mediation through dialogue with the self and make important contributions to the understanding of the psycholinguistic processes involved in the learning of an L2. In the following section, I will discuss the contributions of other researchers who have explored the role of human mediation using what I call, mediation through dialoguing with the other.

\section{Mediation through dialoguing with the other}

According to the sociocultural theory of education, learning is social, that is, we learn through interacting with others, through a meaningful exchange of ideas, concepts, and actions. This premise of Vygotsky's theory has been applied to the field of SLA and has challenged the behaviorist approach that claimed that learning was a passive and individual activity (Lantolf $\&$ Appel, 1994)

This understanding of learning as social, has given SLA teachers new elements to explore their practice and profit from the natural relationship teacher-students and student-student.

The original idea of Vygotsky in relation to human mediation stated that the child should be assisted by an adult in achieving a task he/she could not do alone. This intervention would help the child move towards his/her zone of proximal development, defined by Vygotsky (1978: 86) as “...the distance between the actual development level as determined by independent problem solving and the level of potential development as determined through problem solving under adult guidance or in collaboration with more capable peers" Researches have explored both approaches, that is, adult guidance and peer collaboration, for this reason, I have subdivided this category in two groups, teacher as a mediators, and peers as mediators.

\section{Teacher as a mediator}

It could be said that the role of the teacher has always been of that as a mediator between the learner and the knowledge to be acquired. The teacher is responsible for introducing the learner to new concepts and help him/her walk through this new knowledge until the learners appropriates it. This is not new because teachers have been doing this for centuries. The contribution of the sociocultural theory to the field of education is making the role of the teacher much more interactive, dialogic, and visible.

In what is now known as "traditional classrooms" the pattern of interaction between teachers and students was the following: the teacher asks a question, 
the student answers, and the teacher gives feedback. This is the end of the interaction. In this model, the questions asked by the teacher are, in many occasions, display questions, which presuppose a determined answer from the student. In this structure the student never gets the opportunity to ask the question or to give a creative answer. But this pattern is changing due to new understandings about the relationship between teachers and learners. In what follows, I am going to report on two studies that explore the effects of teacher-students interactions in the second language classroom. The first one is conducted by Gibbons (2003) and the second one by Antón (1999).

For her study, Gibbons explored the interaction between teacher-students in a content-based class, where children were not only learning English as a second language, but also actually using it to access scientific concepts.

The data set was collected from two groups of fifth graders who were working on the science topic of magnetism. Gibbons documents how the interaction between the teacher and the student helps the latter to move from an everyday register to an academic register when describing a scientific concept. The teacher helped the learner develop both at the level of language and at the level of scientific concepts by providing assistance in both fields through questions and feedback., so that the learners could improve not only their English, but also their knowledge in the subject matter.

Antón (1999) also examines the role of teacher assistance to learners. She contrasts the effects of the teacher's role in two different classrooms. One is a class of L2 French in which the teacher implements principles of the Communicative Language Teaching approach and the class is learner-centered, and the other one of L2 Italian, in which the teacher follows the "traditional approach", and the class is teacher-centered.

With the arising of Communicative Language Teaching in the field of SLA, the roles of the teacher and students came into examination (along with all the other elements that compose the teaching-learning process) and given the nature of language assumed by this approach (that language is essentially a communication tool) teachers and students were meant to modify their roles (Brown, 1994). This new role assigned to the teacher aligns with the Vygotskyan concept of human mediation, because in CLT the teacher is not the person who knows-it-all and transmits knowledge, but rather a facilitator that helps students to construct their own knowledge and invite them to be active participants in their learning process. 
In her analysis of data, Antón found that the strategies used by the teacher in the L2 French to help her/his students analyze their mistakes, infer rules, and apply them correctly, were by far more effective than the approach followed by the L2 Italian teacher, who monopolized the class talk and lectured about the rules.

These types of studies lead to the conclusion that the interaction between the teacher and the student is crucial in student's cognitive development and that when the content is meaningful and situated, learning and development do happen.

\section{Peers as mediators}

The other approach to interaction is the one that explores it between peers. As I mentioned above, a broader understanding of peer interaction, sees it as a valuable tool to help learners develop their command of the L2. I will now discuss some research studies that tackle the role of peer interaction either in developing writing or in developing speaking in the L2.

Villamil and de Guerrero (1996) conducted a study to examine what happened when two ESL students worked together in a writing process. They approached writing as a process, in which students are guided by the teacher through several steps to write a piece.

During the last decades, writing has been understood as an active process that requires the mediation of higher psychological functions. In the field of SLA, writing was limited to the production of isolated sentences to practice certain structure or grammar point. This narrow view of writing has changed and currently, SLA teachers pay more attention to develop a process parallel to speaking, listening and reading.

Under the perspective of writing as a process, one of the crucial steps is revision. This task was traditionally undertaken by the teachers who read students' final drafts and wrote feedback that students should incorporate in the final version. In this study this task is handed to peers instead of giving it to the teacher. They should talk about the piece, not just write feedback on the margins of the page. The researchers found that peer revision and dialogue lead the participants to develop several strategies that help them improve their language development.

In the same line of exploring the role of peer mediation in the writing process, Lee (1997) conducted a study with four college Japanese students 
who took a tutorial with the researcher one hour a week. Lee asked the students to turn in various written assignments and they would work in pairs to provide feedback on the piece. The reviews lasted 30-40 minutes and were audio-recorded. After the review, students would rewrite their assignments incorporating his/her peer's feedback.

In her study, Lee found that peers made efforts to help each other improve their writing but interestingly they did not correct grammar, instead, they praised each other's piece. One possible explanation for this behavior, according to Lee, is that students have a strong influence from Confucian philosophy which implies that students are courteous and modest. Despite this lack of grammar correction, students reported they believed their writing skills had improved because they could exchange ideas and discuss them with their peers.

This type of activities, in which peers collaborate in polishing a written piece takes writing to a new dimension because it is not longer seen as the solitary activity it once was, but as the result of two or more heads thinking and producing together, or as DiPardo and Freedman (1988: 123) state: "Groups present and arena for intervening in the individual's writing process, for working collectively to discover ideas, for underscoring the writer's sense of audience, for interacting with supportive others at various points in the composing process, and even, perhaps, for developing the writer's intuition". Besides, according to Wertsch (1985) Vygotsky placed strong emphasis in this kind of peer or small group activities, because the origins of higher mental processes lay in the interaction between or among peers.

Mendoça and Johnson (1994) carried out a study to explore the negotiations that took place between peer reviews of written pieces and how those negotiations shaped students' revision activities. They worked with 12 advanced EFL speakers who were enrolled in different graduate programs in an American university.

The participants had to write a short essay and revise it with a peer. The interaction between the two was audio taped. The researchers found that students used five types of negotiation: 1) Question; 2) Explanation; 3) Restatement; 4) Suggestion; and 5) Grammar correction. Mendoça and Johnson draw two important conclusions: first that peer reviews force students to exercise their thinking and become aware of what they know and what they do not know. Second, they advise teachers to use peer feedback but combine it 
with other forms of feedback because students still consider teacher's feedback to be more beneficial.

\section{Mediation through technology}

The third category I established from the group of studies reported in this review, is mediation through technology, which presents studies that have used the computer as a mediation tool between the language learner and the $\mathrm{L} 2$.

The implementation of technology, for example computers, for language learning, can be traced back from the 1960s, when they were used to replicate the behaviorist approach to teaching. Later in the 1980 s, with the appearance of Communicative Language Teaching and the development of microcomputers, learners had new possibilities for interactive learning. The 1990's was characterized by the introduction of software aimed at stimulating students' motivation, critical thinking, creativity, and analytical skills. Currently, and thanks to the spread of the Internet, learners can make a much integrative use of CALL in order to enhance their L2 skills (Fotos, 2004). Today teachers use CALL in a variety of forms such as word processing, email exchange, multimedia applications, internet, chats, distance learning, IM, etc.

In an attempt to provide teachers with a solid ground to implement the use of computers in the L2 classroom, Warschauer (1997) wrote an article in which he presents a theoretical exploration of computers as mediating tools based on Vygotsky's concept of mediation. The fact that learners' products can be saved on the computer allows teachers and learners to retrieve that information and reflect about it, revise, and improve it. This dynamic creates a community of practice in which teachers and peers work collaboratively to promote the learning of the $\mathrm{L} 2$.

In his research Warschauer identifies five distinguishing features in Computer Mediated Communication (CMC), they are: 1) Text-based and computer-mediated interaction: this feature gives writing a new dimension because it is seen as an interactive skill and becomes a "cognitive amplifier"; 2) Many-to-many communication: any member of a group may initiate interaction with any other and construct knowledge together; 3) Time-andplace-independent communication: users can write or receive messages any time anywhere; 4) Long distance exchanges: CMC gives learners the possibility to interact with other learners that are physically or geographically distant but 
connected through a computer. 5) Hypermedia links: this feature allows the publication and distribution of multimedia documents around the world through the World Wide Web.

In a later study, Fotos (2004) researched the effects of an email exchange program in the L2 classroom. She framed her study theoretically on Vygotsky's idea that children construct meaning interactively and the social exchange of ideas is vital in the individual's development.

The participants of her study were a group of 20 Japanese university EFL students and a group of 5 American university students in which the American students would correspond with four Japanese EFL students for 2 semesters. They were free to choose the topic of the email exchange.

Overall the results showed a positive effect of email exchange in the development of the L2. Fotos identified 5 major categories: 1) Scaffolding (students used their tutor's text to write their replies); 2) Reading and writing for authentic purposes; 3) Face-saving and low concern for errors; 4) Proficiency gains in the target language; and 5) High motivation.

Research like this one demonstrates that email exchange can become a powerful tool teachers can implement in their L2 classrooms to promote meaningful and purposeful reading and writing. As Vygotsky (1978: 117) states "the teaching should be organized in such a way that reading and writing are necessary for something". Knowing that they are interacting with native speakers of the language, through the mediation of the computer, provides learners with context that is difficult to encounter in settings where the L2 is not used outside the classrooms. Besides, as mentioned above, the asynchrony of the communication allows learners to be in control of their own learning because they can decide when and how to approach the tasks.

Ong (1988) considers that the invention of the written system changed dramatically the way of thinking of literate people and in similar ways, $\mathrm{Li}$ (2005) claims that the use of computers "have reshaped the thinking, writing, and revision processes of people who have adapted their composing abilities to the new writing medium". (p. 16) He concludes this from two sources: a group of studies that explored this issue, and his own research on the matter.

Framing his research on the Vygostkyan concept of tool and sign mediation, Li conducted his study with 21 Mandarin speaking adults who 
were proficient speakers of English. His objective was to compare the results of two writing assignments using two different media: computers, and pen and paper. The same group of students participated in both conditions. After conducting a quantitative analysis he found that, for the four independent variables he observed (thinking processes, revisions, quality of essays, and time spent on writing), the group performed better when using the computer than when using pen and paper. These findings lead to the conclusion that computers as mediation tools provide a useful means to motivate students to write in the L2.

Summing up, the three studies reported above contribute to extrapolate Vygotsky's concept of mediation and apply it to other types of tools created and upgraded constantly by human beings to suit their needs, or in Vygotsky's words: "Like words, tools and nonverbal signs provide learners with ways to become more efficient in their adaptive and problem-solving efforts" (1978: 127). Using computers as a means to access, practice, and learn an L2 can not be under estimated by teachers, and as Fotos (2004: 7) states "Technology will not replace teachers; teachers who use technology will replace those who don't".

\section{Conclusion}

One important concept in Vygotsky's theory is mediation. Human beings have developed different tools to mediate between their minds and the world. These tools can be of a different nature and serve different purposes. In the anthology presented here, I discussed several studies that dealt with mediation in different forms, either as a symbolic tool, as in the case of dialoguing with the self, or human mediation, as in the subcategories teacher as a mediator, and peers as mediators, or as a material tool, as presented in the group of studies discussed in the category mediation through technology. All these studies present evidence that support the role of mediation in language learning, they show different ways in which mediation can be established and how positive the results are in the L2 classroom.

Vygotsky was a visionary of his time and the exploration and application of his theories are not exhaustive. Taking into account the dates of the articles included in this anthology, it can be seen that Vygotksyan approaches are rather new in the field of SLA, but his contribution has been so powerful that this field has been divided in two schools of thought: mainstream approaches, and sociocultural approaches. The former considers that learning an L2 is an 
individual activity while the latter, based on Vygotsky's theory, conceive the act of acquiring a language as a social process, and acknowledge the role played by interacting with peers or with more advanced users of the language (Lantolf, 2001, Kramsch, 2002).

The studies reported here are just a sample of the different directions that Vygotsky's ideas are taking in this field, and of the increasing interest and concern of teachers and researchers to improve their teaching practices. Teachers and researchers have the challenge of enriching the field by thinking of new ways to apply and investigate Vygotsky's ideas in order to help their learners develop their skills.

Finally, the fact that the studies included in this anthology are classroombased shows that teaching and researching go hand in hand, and that Vygotsky's theory can have real applications in real contexts. SLA teachers can benefit greatly from these studies because, on the one hand, they provide a sound ground to allow teachers to construct their understanding of Vygotsky's theory, and on the other hand, the type of activities introduced by the researchers are interesting, varied, interactive, feasible, and efficient.

\section{References}

Antón, M. (1999). The discourse of a learner-centered classroom: Sociocultural perspectives on teacher-learner interaction in the second-language classroom. The Modern Language Journal, 83, iii, 303-318.

Appel, G. and Lantolf, J. (1994). Speaking as mediation: A study of L1 and L2 text recall tasks. The Modern Language Journal. Vol. 78.

Brown, D. (1994). Teaching by principles. An interactive approach to language pedagogy. New Jersey: Prentice Hall Regents.

DiCamilla, F. \& Anton, M. (1997). Repetition in the collaborative discourse of L2 learners: a Vygotksyan perspective. Canadian Modern Language Review. V. 53. 609-633.

DiPardo, A. and Freedman, S.W. (1988). Peer response groups in the writing classroom: Theoretic foundations and new directions. Review of Educational Research, 58(2) 119-149 
Donato, R. and McCormick (1994). A sociocultural perspective on language learning strategies: The role of mediation. The Modern Language Journal. Vol. 78.

Fotos, S. (2004). Writing as talking: e-mail exchange for promoting proficiency and motivation in the foreign language classroom. Fotos, S and Browne, $\mathrm{C}$ (Eds.) New perspectives on CALL for second language classrooms. New Jersey: Lawrence Erlbaum Associates.

Fotos, S. and Browne, C. (2004). The development of CALL and current options. Fotos, S and Browne, C. (Eds.) New perspectives on CALL for second language classrooms. New Jersey: Lawrence Erlbaum Associates.

Gibbons, P. (2003). Mediating language learning: Teacher interactions with ESL students in a content-based classroom. TESOL QUARTERLY. Vol. 37, No. 2.

John-Steiner, V. \& Mahn, H. (1996). Sociocultural approaches to learning and development: A Vygotskian framework. Educational Psychologist. 31 (3/4). 191-206.

Kozulin, A. (1998). Psychological tools. A sociocultural approach to education. Cambridge, MA: Harvard University Press.

Lantolf, J and Appel, G. (1994). Theoretical framework: an introduction to Vygotskyan approaches to second language research. In: Lantolf, J and Appel, G (Eds.) Vygotskyan approaches to second language research. NJ: Ablex Publishing Corporation.

Lantolf, J. (2001). Sociocultural theory and second language acquisition. (Ed.) Oxford: Oxford University Press.

Lantolf, J. (2000). Second language learning as a mediated process. Language Teaching: The International Abstracting Journal for Language Teachers, Educators, and Researchers. Vol. 33.

Lee, I. (1997). Peer reviews in a Hong Kong tertiary classroom. TESL Canada Journal. Vol. 15. No. 1. 58-69.

$\mathrm{Li}$, J. (2005). The mediation of technology in ESL writing and its implications for writing assessment. Assessing Writing 11. 5-21

Mendoça, C \& Johnson, K (1994) Peer review negotiations: revision activities in ESL writing instruction. TESOL QUARTERLY. Vol. 28, No. 4. 745-769.

Piaget, J (2001) Language and thought of the child. Abingdo, UK: Routledge

Ohta, A (2001) Second language acquisition processes in the classroom learning Japanese. Mahwah, NJ: Lawerence Erlbaum Associates Publishers.

Ong, W. J. (1988) Orality and Literacy: The Technologizing of the Word. New Accents. Ed. Terence Hawkes. New York: Methuen.

Warschauer, M. (1997). Computer-mediated collaborative learning: theory and practice. The Modern Language Journal, 81, iv. 470-481.

Wertsch, J. (1985). Vygotsky and the social formation of mind. Cambridge: Harvard University Press. 
Villamil, O. and de Guerrero, M. (1996). Peer revision in the L2 classroom: Social-cognitive activities, mediating strategies, and aspects of social behavior. Journal of Second Language Writing. 5 (1)

Vygotsky, L. (1978). Mind in society. The development of higher psychological processes. Cambridge, M.A: Harvard University Press.

Vygotsky, L (1962) Thought and language. New York: The MIT Press, Massachusetts Institute of Technology and John Wiley \& Sons, Inc.

\section{THE AUTHOR}

Carmen Helena Guerrero Nieto is a full time teacher in the MA program of Universidad Distrital Francisco José de Caldas. She holds an MA in Applied Linguistics to the TEFL and currently is studying for her Ph.D in Second Language Acquisition and Teaching in the University of Arizona. Her research interests are teacher education, critical pedagogy, and critical discourse analysis.

E:mail. carguero@yahoo.com 